\title{
Wheat Response to a Soil Previously Irrigated with Saline Water
}

\author{
Marco Antonio Russo*, Adalgisa Belligno, Vito Sardo \\ ${ }^{1}$ Department of Agrochemistry, University of Catania \\ Via Santa Sofia 98, 95130 Catania, Italy \\ ${ }^{2}$ Department of Agricultural Engineering, University of Catania \\ Via Santa Sofia 98, 95130 Catania, Italy
}

Received: 8 April 2009. Accepted: 10 June 2009

\begin{abstract}
A research was conducted aimed at assessing the response of rainfed, lysimeter-grown wheat to various levels of soil salinity, in terms of dry mass production, inorganic and organic components, sucrose phosphate synthase (SPS) and sucrose synthase (SS) activity. One additional scope was the assessment of soil ability to recover from applied salts by means of winter precipitations. The results confirmed the relatively high salt tolerance of wheat, as demonstrated by the mechanisms enacted by plants to contrast salinity at root and leaf level. Some insight was gained in the relationships between salinity and the various inorganic and organic components, as well as with SPS and SS activity. It was demonstrated that in a year with precipitations well below the average values (305 mm vs 500$)$ the leaching action of rain was sufficient to eliminate salts accumulated during summer irrigation with saline water.
\end{abstract}

Key-words: salinity; sugars, sucrose phosphate synthase, organic acid, sorbitol, proline.

\section{Introduction}

The growth of plants may be reduced under salt stress because of (a) an osmotic stress due to lowering of the external water potential or (b) effects of specific ions on metabolic processes ranging from the absorption of nutrients to enzyme activation or inhibition. The ability to synthesize sucrose is a widespread, possibly universal, characteristic of higher plants cells. Sucrose is derived from hexose phosphates through the combined activities of UDP-glucose pyrophosphorylase, sucrose phosphate synthase (SPS) and sucrose synthase (SS). Sucrose synthase appears to be a major control point in sucrose formation during photo assimilation of $\mathrm{CO}_{2}$ (Abdel-latif, 2007). The sucrose status of tissue plays a crucial role in the regulation of metabolism, so that the hydrolysis of sucrose in the sink organs many determine the ability to import pholoassimilates and the sucrolytic ac- tivities, sucrose synthase, acid invertase and neutral invertase could be used as biochemical indicators of sink strength (Balibera et al., 1997).

Sucrose accumulation is acknowledged as a plant feedback response in terms of osmoregulation and crioprotection (Wang et al., 2000), regulating plant photosynthesis and development (Paul and Pellny, 2003), while SPS and SS are the enzymes regulating its biosynthesis. In detail, SPS influences the glucids metabolism (Worrell et al., 1991) as demonstrated by the variations in the sucrose/starch ratio in leaves; $\mathrm{SS}$ is a revealer of the processes of sucrose demolition (Heim et al., 1993). Huber and Huber (1996) suggested that SPS content could be considered as an indicator of source strength under osmotic stress condition. Further, Foyer and Ferrario (1999) reported that the SPS activity seems to be an adaptive control in photosynthesis, assimilate partitioning, carbon export and biomass production under salinity condition. 
Balibera et al. (2000) also found a significant positive correlation between SPS activity and sucrose content of resistant genotype of tomato under salt stress. Salinity causes a reduction in sink activity leading to an increase in sucrose in source leaves and also a decrease in photosynthetic rate by feed back inhibition.

The worldwide concern for the insufficient freshwater resources induces to explore solutions for the sustainable use of non-conventional waters in agriculture; the present research was aimed at assessing wheat response, in terms biomass production, chemical composition and of sucrose accumulation as well as of SPS and SS activation, to a variously saline substrate.

\section{Materials and methods}

Wheat (Triticum aestivum, cv. Ofanto) was planted in 18 lysimeters sized m 1,0 x 1,0 x 1,0 and plants were eventually thinned to twenty per lysimeter. Granulometric components of the soil are sand, silt and clay (57.8, 16.6 and 25.6 respectively).

In the lysimeters an experiment had been conducted, whereby a sunflower crop had been irrigated with variously diluted seawater (S1 and S2 indicate seawater concentrations of 16 and $33 \%$ respectively) with two different leaching fractions (labelled as LF1 and LF2, respectively, corresponding to about 550 and $660 \mathrm{~mm}$ of applied water and 110 and $290 \mathrm{~mm}$ of drained water). As a consequence of the different treatments the soils initially had six levels of salinity, as reported in Table 1; initial values refer to conditions before winter precipitations, which totalled $305 \mathrm{~mm}$, while final values show the effects of rain leaching and wheat crop uptaking. Three replications were used for each treatment and samplings were done at the milky-waxy ripeness phase (127 DAE), with three plants sampled from every lysimeter. After harvesting, the aboveground biomass dry weight was determined.

Furthermore the following analyses were conducted:

- $\mathrm{K}^{+}, \mathrm{Na}^{+}, \mathrm{Ca}^{2+}, \mathrm{PO}_{4}^{3-}$, by spectrophotometry on dry matter, after wet mineralization

- $\mathrm{Cl}^{-}$according to Binzel et al. (1987) method, on fresh matter

- SPS (EC 2.3.1.14) according to the method of Tognetti et al. (1990), permitting to assess the highest (-P) and lowest $(+\mathrm{P})$ enzyme activity: the addition of phosphoric acid to the system inhibits the synthesis of sucrose and represents directly the minimal enzyme activity $(+\mathrm{P})$ and indirectly the SS activity

- glucose, fructose, sucrose, sorbitol and citric and malic acids, by chromatography, according to the method of Li and Schumann (1981)

- total proteins (Bradford, 1976) and proline content (Bates et al., 1973).

The results were analysed by means of a one-way analysis of variance (ANOVA), using Tukey test to compare the means. Different letters indicate significant differences at $\mathrm{P} \leq 0.05$.

\section{Results}

In table 2 the dry weights of the wheat aboveground biomass are reported, showing the limited influence of the initial soil salinity on the final plant development, thanks also to the sufficient (although less than average) precipitations occurred during the winter. Organic acid shows a significant increase with salinity, independently on LF, even though with higher value for citric acid. Also the glucose and sorbitol increases with salinity, with higher extent at the S2 and for the LF2 (Tab. 3).

Table 1 . Soil salinity evolution.

\begin{tabular}{lcccccc}
\hline $\begin{array}{l}\text { Previous } \\
\text { Treatment }\end{array}$ & $\begin{array}{c}\text { Initial ECe } \\
\left.(\mathrm{dS} \mathrm{m})^{-1}\right)\end{array}$ & $\begin{array}{c}\text { Final ECe } \\
\left.(\mathrm{dS} \mathrm{m})^{-1}\right)\end{array}$ & $\begin{array}{c}\text { Initial Cl} \\
\left(\mathrm{mol} \mathrm{L}^{-1}\right)\end{array}$ & $\begin{array}{c}\text { Final Cl} \\
\left(\mathrm{mol} \mathrm{L}^{-1}\right)\end{array}$ & $\begin{array}{c}\mathrm{Initial} \mathrm{Na}^{+} \\
\left(\mathrm{mol} \mathrm{L}^{-1}\right)\end{array}$ & $\begin{array}{c}\mathrm{Final} \mathrm{Na}^{+} \\
\left(\mathrm{mol} \mathrm{L}^{-1}\right)\end{array}$ \\
\hline ControlLF1 & 1.14 & 0.68 & 0.011 & 0.005 & 0.007 & 0.003 \\
ControlLF2 & 1.10 & 0.79 & 0.011 & 0.007 & 0.007 & 0.005 \\
S1 LF1 & 8.98 & 1.34 & 0.189 & 0.007 & 0.124 & 0.004 \\
S2 LF1 & 10.48 & 2.63 & 0.198 & 0.011 & 0.130 & 0.007 \\
S1 LF2 & 12.19 & 2.31 & 0.194 & 0.010 & 0.127 & 0.007 \\
S2 LF2 & 19.85 & 3.08 & 0.203 & 0.010 & 0.133 & 0.007 \\
\hline
\end{tabular}

Soil: water $=1: 5$. 
Table 2. Dry weight (d.w.) of aboveground biomass (g plant $\left.{ }^{-1}\right)$ and selected ion content in biomass (\% dry matter).

\begin{tabular}{llllllll}
\hline Previous treatment & d.w. & $\mathrm{K}^{+}$ & $\mathrm{Ca}^{2+}$ & $\mathrm{Na}^{+}$ & $\mathrm{PO}_{4}{ }^{3-}$ & $\mathrm{Cl}^{-}$ & $\mathrm{NO}_{3}^{-}$ \\
\hline C LF1 & $18 \mathrm{a}$ & $2.46 \mathrm{c}$ & $0.49 \mathrm{~b}$ & $0.15 \mathrm{~d}$ & $0.57 \mathrm{a}$ & $0.35 \mathrm{~d}$ & $2.41 \mathrm{c}$ \\
C LF2 & $13 \mathrm{~cd}$ & $4.65 \mathrm{a}$ & $0.50 \mathrm{~b}$ & $0.15 \mathrm{~d}$ & $0.52 \mathrm{a}$ & $0.23 \mathrm{e}$ & $3.47 \mathrm{a}$ \\
S1 LF1 & $13 \mathrm{~cd}$ & $3.17 \mathrm{~b}$ & $0.50 \mathrm{~b}$ & $0.46 \mathrm{~b}$ & $0.46 \mathrm{~b}$ & $0.86 \mathrm{~b}$ & $2.60 \mathrm{c}$ \\
S2 LF1 & $12 \mathrm{~d}$ & $1.23 \mathrm{~d}$ & $0.52 \mathrm{~b}$ & $0.50 \mathrm{a}$ & $0.46 \mathrm{~b}$ & $0.92 \mathrm{a}$ & $2.18 \mathrm{~d}$ \\
S1 LF2 & $16 \mathrm{~b}$ & $1.19 \mathrm{~d}$ & $0.53 \mathrm{~b}$ & $0.26 \mathrm{c}$ & $0.41 \mathrm{c}$ & $0.67 \mathrm{c}$ & $2.91 \mathrm{~b}$ \\
S2 LF2 & $14 \mathrm{c}$ & $1.17 \mathrm{~d}$ & $0.68 \mathrm{a}$ & $0.50 \mathrm{a}$ & $0.42 \mathrm{c}$ & $0.69 \mathrm{c}$ & $2.27 \mathrm{~d}$ \\
\hline
\end{tabular}

Mean values followed by different letters are significantly different at $\mathrm{P} \leq 0.05$.

Table 3. Content in organic acids, carbohydrates and sorbitol (mg $100 \mathrm{~g}^{-1}$ dry matter).

\begin{tabular}{lcccccc}
\hline Treatment & Citric acid & Malic acid & Sorbitol & Sucrose & Fructose & Glucose \\
\hline Control LF1 & $29.07 \mathrm{c}$ & $14.90 \mathrm{~d}$ & $0.44 \mathrm{e}$ & $140.40 \mathrm{~d}$ & $129.32 \mathrm{~b}$ & $71.36 \mathrm{~d}$ \\
Control LF2 & $30.38 \mathrm{c}$ & $14.25 \mathrm{e}$ & $0.58 \mathrm{~d}$ & $229.74 \mathrm{a}$ & $118.35 \mathrm{c}$ & $71.24 \mathrm{~d}$ \\
\hline S1 LF1 & $42.26 \mathrm{~b}$ & $14.97 \mathrm{~d}$ & $0.68 \mathrm{c}$ & $121.24 \mathrm{e}$ & $107.29 \mathrm{~d}$ & $76.92 \mathrm{c}$ \\
S2 LF1 & $41.45 \mathrm{~b}$ & $16.19 \mathrm{c}$ & $0.76 \mathrm{~b}$ & $121.06 \mathrm{e}$ & $129.32 \mathrm{~b}$ & $90.95 \mathrm{~b}$ \\
S1 LF2 & $42.65 \mathrm{~b}$ & $19.53 \mathrm{~b}$ & $0.73 \mathrm{~b}$ & $164.74 \mathrm{~b}$ & $122.97 \mathrm{~b}$ & $83.45 \mathrm{~b}$ \\
S2 LF2 & $55.65 \mathrm{a}$ & $20.94 \mathrm{a}$ & $1.19 \mathrm{a}$ & $157.83 \mathrm{c}$ & $203.43 \mathrm{a}$ & $143.25 \mathrm{a}$ \\
\hline
\end{tabular}

As in Table 2.

The SPS activity of wheat leaves is highly affected by sea water treatments decreasing significantly in both LF, more pronounced for LF2 (from 4.13 in the control to 1.76 and 1.45 $\mu \mathrm{mol}^{*}$ hour $^{-1} * \mathrm{~g}^{-1}$ fresh matter in S1 and S2, respectively) than for LF1 where the values were always higher (Tab. 4). Protein content shows a continuous decrease as the salinity increases, whereas proline increases with salinity, with higher extent at the S2 (Tab. 4).

\section{Discussion and conclusions}

From the inspection of Tables 1 to 4 conclusions of some interest can be drawn. Table 1 shows the evolution of EC in the soils in treatments S1 - S2 from the high initial values to the final ones, as a consequence of the leaching action of the precipitations $(305 \mathrm{~mm})$ and salt uptaking from plants, although in negligible amounts: it can be appreciated that EC was substantially reduced in spite of the unusually low precipitation amount, to the extent that probably conditions of sustainability can be expected under the average conditions (over $500 \mathrm{~mm} /$ year). This interesting aspect deserves further investigation, however. One further aspect of interest is the low impact of initial, final and averaged soil salinity values, as expressed by $\mathrm{EC}_{\mathrm{e}}$ values, on biomass yield; it is not easy to accurately assess the effects of plant tolerance due to the varying salinity levels in the soil, but an analysis of data in tables 5-7 can help in finding some clue. Plant tolerance is evidenced by the relatively high content in $\mathrm{Ca}^{2+}$ and $\mathrm{K}^{+}$, indicating a plant ability to buffer $\mathrm{Na}^{+}$with an efficient $\mathrm{Ca}^{2+} / \mathrm{Na}^{+}$ exchange system, in a homeostasis mechanism

Table 4. Range of activity of SS and SPS (_mol*hour ${ }^{-1} * \mathrm{~g}^{-1}$ fresh matter), proline and total proteins (\% dm).

\begin{tabular}{lcccc}
\hline Treatment & SS (min) & SPS (max) & $\begin{array}{c}\text { Proline } \\
\left(\mu \mathrm{g} \mathrm{g}^{-1} \mathrm{dm}\right)\end{array}$ & $\begin{array}{c}\text { Total proteins } \\
(\% \mathrm{dm})\end{array}$ \\
\hline Control LF1 & $2.10 \mathrm{c}$ & $4.08 \mathrm{a}$ & $0.84 \mathrm{~b}$ & $2.72 \mathrm{a}$ \\
Control LF2 & $0.87 \mathrm{e}$ & $4.13 \mathrm{a}$ & $0.45 \mathrm{e}$ & $2.15 \mathrm{c}$ \\
S1 LF1 & $2.73 \mathrm{~b}$ & $2.65 \mathrm{~b}$ & $0.50 \mathrm{~d}$ & $2.57 \mathrm{bc}$ \\
S2 LF1 & $2.79 \mathrm{~b}$ & $1.79 \mathrm{c}$ & $1.09 \mathrm{a}$ & $2.45 \mathrm{c}$ \\
S1 LF2 & $1.65 \mathrm{~d}$ & $1.76 \mathrm{c}$ & $0.65 \mathrm{c}$ & $1.97 \mathrm{~cd}$ \\
S2 LF2 & $3.55 \mathrm{a}$ & $1.45 \mathrm{~d}$ & $0.83 \mathrm{~b}$ & $1.91 \mathrm{~d}$ \\
\hline
\end{tabular}

As in Table 2. 
typical of salt tolerating plants (Yokoi et al. 2002). It is known, indeed, that high amounts of $\mathrm{Ca}^{2+}$, play an essential role in limiting the damage due to $\mathrm{NaCl}$ since $\mathrm{Ca}^{2+}$ helps the "Na exclusion" avoiding, in this way, damages to biomembranes (Colmer et al., 1996). Externally supplied $\mathrm{Ca}^{2+}$ reduces the toxic effects of $\mathrm{NaCl}$, presumably by facilitating higher $\mathrm{K}^{+} / \mathrm{Na}^{+}$selectivity; the plants, thus, regulate the expression and activity of $\mathrm{K}^{+}$and $\mathrm{Na}^{+}$transporters and of $\mathrm{H}^{+}$pumps that generate the driving force for transport. High salinity also triggers increased cytosolic $\mathrm{Ca}^{2+}$ that is transported from the apoplast and intracellular compartments. The resultant transient $\mathrm{Ca}^{2+}$ increase elicits stress signal transduction and leads to salt adaptation (Parida and Das, 2005).

The involvement of $\mathrm{Ca}^{2+}$ in salt tolerance has already been shown by Jang et al. (1998) who have observed an induction of a $\mathrm{Ca}^{2+}$-binding protein in salt-stressed Arabidopsis. Moreover, after salinization, an increase of mRNA levels of a $\mathrm{Ca}^{2+}$-ATPase and of a $\mathrm{Ca}^{2+}$-dependent protein kinase has been observed in tomato (Wimmers et al., 1992) and in mungbean (Botella et al., 1996).

The accumulation of nitrogen-containing compatible solutes including proline is known to function in osmotic adjustment, protection of cellular macromolecules from damage by salts, storage of nitrogen and scavenging of free radicals. Some authors have, however, argued that excessively high levels of proline accumulation may be a response to leaf damage when exposed to high salt concentrations and that a higher level of proline accumulation is associated with salt sensitive traits in tomato and sorghum. Proline accumulation in response to lower salt concentrations may contribute positively to salt tolerance, whereas the extremely high concentration in leaf tissues under high salinity treatment may be partly due to leaf damage. Also the trend of glucose, sorbitol and organic acid percentages, rising with soil salinity, indicates the plant ability to contrast lower osmotic values in the soil (Dubey and Singh, 1999; Kerepesi and Galiba, 2000; Mahn et al., 2002). The reaction of SPS to soil salinity values concurs to show an adaptive plant response to salts, obtained through the different utilization of the monosaccharide component by this enzyme, as remarked in other stress conditions
(Yoshida et al., 1998). The sharply decreasing SPS activity in response to soil salinity suggests in fact a larger production of hydrolyzed molecules, in accordance with increasing sorbitol, glucose and organic acids: such increase in osmo-compatible components can be seen as a defence mechanism enacted by plants to determine the osmotic adjustment required to contrast salt stress depending on the enhanced translocation of $\mathrm{Na}^{+}$from roots to leaves (Balibrea et al., 1997; Gao et al., 1998; Kerepesi and Galiba, 2000). Plant ability to uptake the phosphate ion resulted inversely correlated to $\mathrm{EC}_{\mathrm{e}}$, unlike the nitrate ion which showed no correlation to $\mathrm{EC}_{\mathrm{e}} \cdot \mathrm{Cl}^{-}$and $\mathrm{Na}^{+}$did not display on such anions the influence which has been found by other researchers (e.g. Hocking, 1993; Cerezo et al., 1997; Ivashikina and Feyeziev, 1998).

\section{References}

Abdel-latif A. 2007. Response of Maize Leaf Sucrose Phosphate Synthase to Salinity. Research Journal of Agriculture and Biological Sciences, 3, 6:930-933.

Balibera ME., Rus-Alvarez A.M., Bolerin M.C., PerezAlfoncera F. 1997. Fast changes in soluble carbohydrate and praline contents in tomato seedlings response to ioni and non-ionic- iso-osmotic stesses. J Plant Physiol., 151:221-226.

Balibrea M., Jose D.A., Bolarin M.C., Alfucca F.P. 2000. Carbon partitioning and sucrose metabolism in tomato plants growing under salinity. Physiol. Plant., I, 10:5032-511.

Bates LS., Waldren RP., Teare ID. 1973. Rapid determination of free proline for water stress studies. Plant Soil, 39:205-207.

Binzel M.L., Hasegawa P.M., Rhodes D., Handa S., Handa A.K., Bressan R.A. 1987. Solute accumulation in tobacco cells adapted to NaCl. Plant Physiol, 84:14081415.

Botella J.R., Arteca J.M., Somodevilla M., Arteca R.N. 1996. Calcium-dependent protein kinase gene expression in response to physical and chemical stimuli in mungbean (Vigna radiata). Plant Molecular Biology, 30:1129-1137.

Bradford M.M. 1976. A rapid and sensitive method for the quantitation of microgram quantites of protein utilizing the principle of protein-dye binding. Anal. Biochem, 72:248-254.

Cerezo M., Garcia-Augustin P., Serna M.D., Primo Millo E. 1997. Kinetics of nitrate uptake by citrus seedlings and inhibitory effects of salinity. Plant Science, 126:105-112.

Colmer T.D., Fan T.W.M., Higashi R.M., Lauchli A. 1996. Interactive effects of $\mathrm{Ca}^{2+}$ and $\mathrm{NaCl}$ salinity on the 
ionic relations and proline accumulation in the primary root tip of Sorghum. Physiologia Plantarum, 97:421-424.

Dubey R.S., Singh A.K. 1999. Salinity induces accumulation of soluble sugars and alters the activity of sugar metabolism enzymes in rice plants. Biologia Plantarum, 42:33-239.

Foyer C.H., Ferrario S. 1999. Modulation of carbon nitrogen metabolism in transgenic plant with a view to impre biomass production. Biochem. Sci. Trans., 22:909-915.

Gao Z., Sagi M. Lips S.H. 1998. Carbohydrate metabolism in leaves and assimilate partitioning in fruit of tomato (Lycopersicum esculentum L.) as affected by salinity. Plant Sci., 135:149-159.

Heim U., Weber H., Baumlein H., Wobus U. 1993. A sucrose-syntase gene of Vicia faba L.: Expression pattern in developing seeds in relation to starch synthesis and metabolic regulation. Plante, 191:394-401.

Hocking P.J. 1993. Distribution and redistribution of mineral nutrients and dry matter in grain sorghum as affected by soil salinity. J. Plant Nutr., 16, 9:17531774.

Huber S.C., Huber L. 1996. Role and Regulatior sucrose phosphate synthase in higher plants. Annu. Rev. PI. Physiol and Plant Mol. Biol., 47:431-444.

Jang H.J., Pih K.T., Kang S.G., Lim J.H., Jin J.B., Piao H.L., Hwang I. 1998. Molecular cloning of a novel $\mathrm{Ca}^{2+}$-binding protein that is induced by $\mathrm{NaCl}$ stress. Plant Molecular Biology, 37:839-847.

Ivashikina N.V., Feyziev Ya.M. 1998. Regulation of nitrate uptake in maize seedlings by accompanying cations. Plant Science, 131:25-34.

Kerepesi I., Galiba G. 2000. Osmotic and salt stress-induced alteration in soluble carbohydrate content in wheat seedlings. Crop Science, 40:482-487.

Li B.W., Schuhmann P.J. 1981. Gas Chromatographic analysis of sugars in granola cereals. J. Food Sci., 46:425.

Mahn K., Hoffmann C., Märländer B. 2002. Distribution of quality components in different morphological sections of sugar beet (Beta vulgaris L.). Eur. Journal of Agr., 17:29-39.

Parida A.K., Das A.B. 2005. Salt tolerance and salinity effects on plants: a review. Ecotoxicology and Environmental Safety, 60:324-349.

Paul M.J., Pellny T.K. 2002. Carbon metabolite feedback regulation of leaf photosynthesis and development. Journal of Experimental Botany, 54:539-547.

Tognetti J.A., Salerno G.L., Crespi M.D., Pontis H.G. 1990. Sucrose and fructan metabolism in different wheat cultivars at chilling temperatures. Physiologia Plantarum, 78:554-559.

Wang H.L., Lee P.D., Chen W.L., Huang D.J., Su J.C. 2000. Osmotic stress-induced changes of sucrose metabolism in cultured sweet potato cells. J. Experimental Botany, 51, 353:1991-1999.

Wimmers L.E., Ewing N.N., Bennett A.B. 1992. Higher plant $\mathrm{Ca}^{2+}$-ATPase: primary structure and regulation of mRNA abundance by salt. Proceedings of the National Academy of Science USA, 89:9205-9209.

Worrel A.C., Bruneau J.M., Summerfelt K., Boersin M., Voelker T.A. 1991. Expression of a amize sucrose phosphate synthase in tomato alters leaf carbohydrate partitioning. Plant Cell, 3:1121-1130.

Yokoi S., Quintero F.J., Cubero B., Ruiz M.T., Bressan R.A., Hasegawa P.M., Pardo J.M. 2002. Differential expression and function of Arabidopsis thaliana NHX Na $\mathrm{Na}^{+} / \mathrm{H}^{+}$antiporters in the salt stress response. Plant J., 30:529-539.

Yoshida M., Abe J., Moriyama M., Kuwabara T. 1998. Carbohydrate levels among winter wheat cultivars varying in freezing tolerance and snow melt resistance during autumn and winter. Physiologia Plantarum, 103:8-16. 